\title{
HUBUNGAN KADAR KOLESTEROL HIGH DENSITY LIPOPROTEIN DARAH DENGAN KADAR HIGH SENSITIVITY C-REACTIVE PROTEIN PADA REMAJA OBES
}

\author{
Jonathan Hanni Surentu \\ Murniati Tiho \\ Yanti M. Mewo

\begin{abstract}
Bagian Biokimia Fakultas Kedokteran Universitas Sam Ratulangi Manado
Email: jonathan.surentu@yahoo.com
\end{abstract}

\begin{abstract}
World Health Organization declared that obesity was a global epidemy (1,7 billion people obese). Obesity has a strong correlations with low high-density lipoprotein cholesterol (HDLc) level. Low HDLc level is the risk factor of coronary heart disease (CHD). High sensitivity C-reactive protein (hs-CRP) is an inflammatory marker in our body. Joint Committee of American Heart Association recommend hs-CRP examination as a risk factor of CHD. The research have aim to know the correlations of HDLc level with hs-CRP on obese adolescent. This research was an observational analytic cross-sectional approach. The population of this research are all obese students at Faculty of Medicine Sam Ratulangi University Manado with Body Mass Index (BMI£ 95th centile, and the samples are all of the population. The result, more of half $(58,8 \%)$ obese adolescents have normal HDLc level. And also found that more of half $(52,9 \%)$ obese adolescents have hs-CRP level with intermediate risk and two samples (11,8\%) with high risk. The result of statistical analysis using the Spearman test showed the correlations $(r)=-0,219$ and the significance $(p)=0,399$. There was no correlations between HDLc level with hs-CRP in obes adolescent.
\end{abstract}

Keywords: Obesity, adolescent, HDLc, hs-CRP, CHD

\begin{abstract}
Abstrak: Organisasi Kesehatan Dunia (WHO) mendeklarasikan obesitas sebagai epidemik global (1,7 miliar penduduk dunia obes). Obesitas memiliki hubungan yang erat dengan rendahnya kadar kolesterol high density lipoprotein (HDL) darah. Rendahnya kadar kolesterol HDL merupakan faktor risiko penyakit jantung koroner (PJK). High sensitivity C-reactive protein (hs-CRP) merupakan suatu penanda peradangan dalam tubuh. Joint Committee of American Heart Association merekomendasikan pemeriksaan hs-CRP sebagai faktor risiko PJK. Tujuan penelitian ini untuk mengetahui hubungan kadar kolesterol HDL darah dengan kadar hs-CRP pada remaja obes. Penelitian ini menggunakan desain penelitian analitik observasional dengan pendekatan cross-sectional. Populasi pada penelitian ini adalah Mahasiswa obes Fakultas Kedokteran Universitas Sam Ratulangi Manado dengan IMT pada persentil $\geq 95$. Sampel diambil dari seluruh populasi. Hasil penelitian didapatkan lebih dari setengah (58,8\%) remaja obes memiliki kadar kolesterol HDL di atas normal. Didapati juga lebih dari setengah (52,9\%) remaja obes memiliki kadar hs-CRP dengan risiko menengah dan dua sampel $(11,8 \%)$ dengan risiko tinggi. Hasil uji statistik spearman antar dua variabel didapati koefisien korelasi $(r)=-0,219$ dan nilai signifikansi $(\mathrm{p})=0,399$. Berdasarkan hasil analisis dapat disimpulkan bahwa tidak terdapat hubungan antara kadar kolesterol HDL darah dengan kadar hs-CRP pada remaja obes.
\end{abstract}

Kata kunci: Obesitas, remaja, kolesterol HDL, hs-CRP, PJK 
Obesitas saat ini menjadi permasalahan dunia bahkan Organisasi Kesehatan Dunia (World Health Organization, WHO) mendeklarasikan sebagai epidemik global (1,7 miliar penduduk dunia obes). Prevalensi anak-anak dan remaja dengan berat badan lebih dan obesitas di Amerika pada tahun 2009-2010 sebesar 30,4\% (1). Kerugian yang disebabkan oleh masalah kesehatan akibat obesitas di Amerika tiap tahun sekitar 147 miliar dolar (2). Indonesia sendiri berdasarkan hasil Riset kesehatan dasar (Riskesdas) tahun 2010 menunjukkan prevalensi obesitas pada remaja usia 13-15 tahun yang berjenis kelamin laki-laki sebesar 2,9\% dan perempuan 2,0\%, sedangkan untuk usia 16-18 tahun masing-masing sebesar 1,3\% dan 1,5\%. Menurut Data Kesehatan Indonesia tahun 2010, prevalensi dewasa obes di Sulawesi Utara sebesar 21,9\% dimana Sulawesi Utara menempati peringkat pertama di Indonesia (3).

Kolesterol HDL sering disebut sebagai kolesterol baik yang memiliki lebih banyak molekul protein dibandingkan lemak. Kolesterol HDL bertindak sebagai vacuum cleaner yang membersihkan lemak-lemak berlebih agar tidak terjadi penimbunan lemak di pembuluh darah. Banyak penelitian mengatakan bahwa penderita obes memiliki kadar kolesterol HDL dibawah normal. Menurut National Cholesterol Education Programme, Adult Panel Treatment III (NCEP-ATP III), selain kolesterol low density lipoprotein (LDL), nilai kolesterol HDL di bawah normal juga merupakan faktor risiko penyakit jantung koroner (PJK) (4).

Dewasa ini, banyak dilakukan penelitian tentang suatu penanda PJK selain kolesterol LDL dan HDL yaitu penanda high sensitivity C-reactive protein (hs-CRP). Studi epidemiologi maupun meta-analisis mengatakan bahwa individu dengan kadar hs-CRP tinggi meningkatkan faktor risiko terkena PJK di kemudian hari. Kadar hs-CRP yang tinggi ini disebabkan karena terjadinya peradangan dalam pembuluh darah arteri koronaria akibat penimbunan lemak (proses aterosklerosis) dan sebab lainnya. Joint Committee of the American Heart Association telah merekomendasikan pemeriksaan hs-CRP sebagai faktor risiko PJK (5).

Kadar kolesterol HDL yang normal sebenarnya dapat mengatasi masalah penimbunan lemak tersebut, namun pada penderita obes kadar kolesterol HDL relatif dibawah normal. Penelitian yang dilakukan terhadap 1.561 pasien dengan faktor risiko PJK tinggi di Rumah Sakit St. Mary Korea, didapatkan adanya hubungan yang signifikan antara kadar hs-CRP dengan kadar kolesterol HDL (6). Bukan hanya pada dewasa obes, pada anak-anak dan remaja dengan obesitas sentral juga didapatkan peningkatan kadar hs-CRP yang signifikan (7).

\section{METODE PENELITIAN}

Penelitian ini menggunakan desain penelitian observasi analitik dengan pendekatan cross-sectional. Lokasi penelitian bertempat di Fakultas Kedokteran Universitas Sam Ratulangi Manado dan pemeriksaan sampel darah dilakukan di Laboratorium Prodia Manado. Penelitian ini dilakukan selama 4 bulan (September 2013-Januari 2014). Populasi dalam penelitian ini ialah mahasiswa obes Fakultas Kedokteran angkatan 2011, 2012, dan 2013 dan jumlah sampel yang diambil ialah seluruh populasi yang sesuai dengan kriteria inklusi dan eksklusi. Data yang telah diperoleh dari hasil pemeriksaan laboratorium diolah menggunakan program Statistical Program for Social Science (SPSS) dengan analisis univariat dan bivariat. Analisis univariat dilakukan untuk melihat frekuensi, rata-rata, nilai terkecil, nilai terbesar, dan standar deviasi pada setiap data yang didapat. Analisis bivariat untuk melihat hubungan antar dua variabel digunakan uji nonparametrik Spearman karena data yang didapat tidak berdistribusi normal. 


\section{HASIL PENELITIAN}

\section{Karakteristik responden}

Responden penelitian ialah mahasiswa obes Fakultas Kedokteran Universitas Sam Ratulangi Manado, angkatan 2011, 2012, dan 2013 dengan IMT pada persenti叉 95. Jumlah responden pada penelitian ini berjumlah 17 orang.

Berdasarkan jenis kelamin diketahui, responden laki-laki berjumlah 11 responden $(64,7 \%)$ dan responden perempuan berjumlah 6 responden (35,3\%). Berdasarkan usia diketahui, responden terbanyak berusia 17 tahun dengan jumlah 8 responden $(47,1 \%)$ dan jumlah responden yang paling sedikit berada pada usia 19 dan 20 tahun yaitu masing-masing 1 responden $(5,9 \%)$.

\section{Kolesterol high density lipoprotein dan high sensitivity $C$-reactive protein}

Hasil laboratorium menunjukkan rata-rata nilai kadar kolesterol HDL darah responden ialah 42,24 mg/dL $\pm 6,14 \mathrm{mg} / \mathrm{dL}$ dengan nilai minimum sebesar $34 \mathrm{mg} / \mathrm{dL}$ dan nilai maksimum sebesar $53 \mathrm{mg} / \mathrm{dL}$. Nilai rata-rata kadar hs-CRP responden ialah 1,73 mg/L $\pm 1,44$ $\mathrm{mg} / \mathrm{L}$ dengan nilai minimum sebesar $0,2 \mathrm{mg} / \mathrm{L}$ dan nilai maksimum sebesar $5 \mathrm{mg} / \mathrm{L}$.

Tabel 1. Analisis univariat kadar kolesterol HDL dan kadar hs-CRP

\begin{tabular}{lccccc}
\hline & $\mathrm{N}$ & Minimum & Maximum & Mean & Std. Deviation \\
\hline Kadar Kolesterol HDL & 17 & 34 & 53 & 42.24 & 6.149 \\
Kadar hs-CRP & 17 & .2 & 5.0 & 1.729 & 1.4443 \\
Valid N (listwise) & 17 & & & & \\
\hline
\end{tabular}

\section{Hubungan kadar kolesterol high density lipoprotein darah dengan kadar high sensitivity $C$-reactive protein}

Uji statistik yang digunakan untuk menilai hubungan antar dua variabel ialah uji nonparametrik Spearman karena data yang didapat tidak berdistribusi normal. Hasil uji statistik menunjukkan nilai koefisien korelasi $(r)=-0,219$ dan nilai signifikansi $(p)=0,399$. Hal ini menunjukkan bahwa kadar kolesterol HDL darah dengan kadar hs-CRP pada mahasiswa obes dengan IMT pada persentil $\geq 95$ me miliki hubungan ke arah negatif, lemah, dan tidak signifikan.

Tabel 2. Analisis bivariat hubungan kadar kolesterol HDL dengan kadar hs-CRP

\begin{tabular}{lcc}
\hline & $\mathrm{r}$ & $\mathrm{p}$ \\
\hline Kadar kolesterol HDL & -.219 & .399 \\
Kadar hs-CRP & & \\
\hline
\end{tabular}




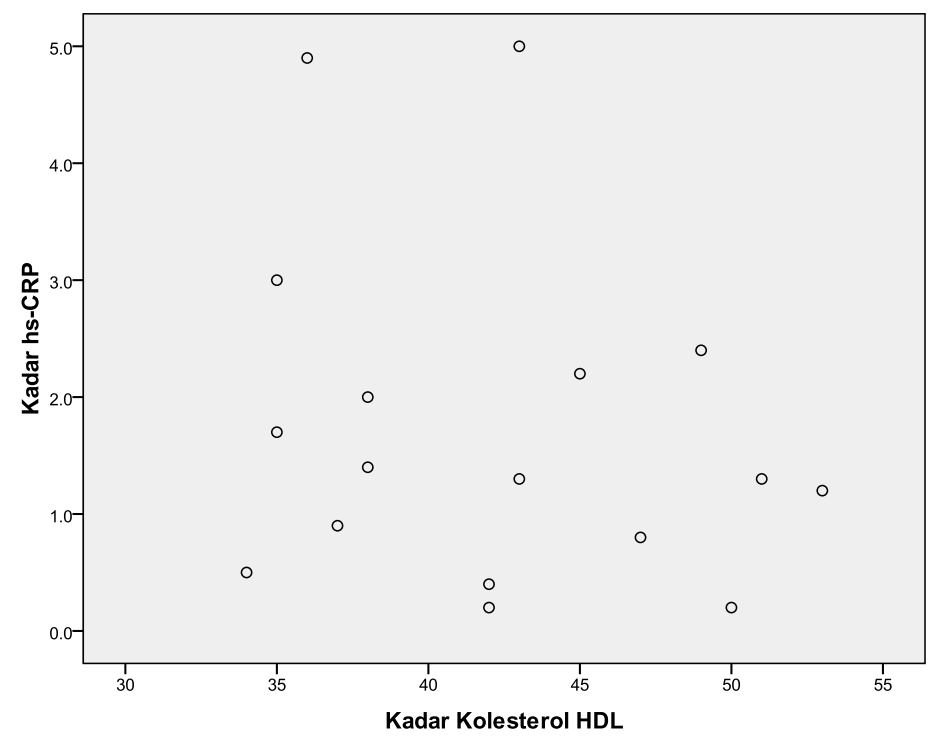

Gambar 1. Scatter Plot

\section{BAHASAN}

Hasil laboratorium dalam penelitian ini menunjukkan lebih dari setengah $(58,8 \%)$ remaja obes memiliki kadar kolesterol HDL dalam rentang normal. Hasil ini bertentangan dengan teori dan beberapa penelitian sebelumnya. Penelitian yang dilakukan Whitney et al didapati keadaan dislipidemia pada anak-anak dan remaja obes di kota Meksiko, pada penelitian tersebut kadar kolesterol HDL pada anak-anak dan remaja obes lebih rendah dibandingkan dengan anak-anak dengan berat badan normal (8). Hal yang sama juga dibuktikan pada penelitian yang dilakukan oleh Sabine et al, terhadap remaja obes dengan usia 13-19 tahun di Belanda (9). Rendahnya kadar kolesterol HDL juga didapati oleh Sargowo dkk dalam penelitian yang dilakukan pada remaja obes di Kota Malang. Baik remaja laki-laki maupun perempuan juga memiliki kadar kolesterol HDL di bawah normal (10).

Kadar kolesterol HDL tidak hanya dipengaruhi oleh ukuran antropometri seseorang, hal ini bisa menjadi pertimbangan dari hasil yang didapat penulis. Beberapa faktor yang juga mempengaruhi kadar kolesterol HDL antara lain genetik dan pola hidup. Penelitian multi etnik yang dilakukan pada 33 remaja obes ras Amerika asli, 33 remaja obes ras AfrikaAmerika, dan 33 remaja obes ras Hispanik, ternyata tiap ras memiliki rentang nilai kadar kolesterol HDL yang berbeda-beda dimana ras Afrika-Amerika cenderung memiliki kadar kolesterol HDL lebih tinggi (11). Penelitian yang dilakukan Toni Mustahsani, di Kecamatan Tanjung Sari, Jawa Barat, ternyata berat badan lahir juga mempengaruhi kadar kolesterol HDL dimana anak dengan berat badan lahir rendah (BBLR) berisiko memiliki kadar kolesterol HDL dibawah normal di kemudian hari (12). Penelitian meta-analisis yang dilakukan Feng et al juga membuktikan bahwa kadar kolesterol HDL dipengaruhi oleh faktor genetik (13).

Aktivitas fisik juga menentukan kadar kolesterol HDL seseorang. Aktivitas fisik akan merangsang Lipoprotein Lipase (LPL) di permukaan otot rangka, jaringan adiposa, dan hati. Peningkatan LPL akan meningkatkan hidrolisis dari triasilgliserol (TAG). Triasilgliserol akan dipecah menjadi asam lemak bebas dan gliserol, bersamaan dengan itu, kolesterol bebas dan fosfolipid yang ada di permukaan TAG akan ikut terlepas. Aktivitas fisik juga meningkatkan kerja dari AMP-activated protein kinase (AMPK) dan Silent regulator T1 (SIRT1). 
Peningkatan kerja dari AMPK dan SIRT1 akan merangsang peroxisome ploriferatoractivated receptor (PPAR) di hati untuk meningkatkan sintesis dari apo A-I. Apo A-I yang terbentuk akan berikatan dengan kolesterol bebas dan fosfolipid yang terlepas dari TAG untuk membentuk HDL baru, sehingga meningkatkan kadar kolesterol HDL darah (14). Banyak penelitian juga mendukung teori di atas. Studi literatur yang dilakukan ternyata sudah ada 25 penelitian tentang pengaruh senam aerobik terhadap peningkatan kadar HDL, dan semua menunjukkan bahwa senam aerobik meningkatkan kadar kolesterol HDL dengan signifikan (15).

Pola makan juga mempengaruhi kadar kolesterol HDL. Hal ini dibuktikan melalui penelitian yang dilakukan Di Renzo et al, wanita dengan profil lipid yang tidak normal, setelah 7 hari mengonsumsi dark chocolate, ternyata didapati peningkatan yang signifikan dari kadar kolesterol HDL (16). Penelitian yang dilakukan Daniel et al menyatakan bahwa wanita dengan berat badan lebih yang gemar mengonsumsi tomat ternyata memiliki kadar kolesterol HDL yang normal (17). Hal yang sama juga diperoleh Iris et al, setelah 2 bulan mengonsumsi buah beri, terjadi peningkatan kadar kolesterol HDL yang bermakna (18). Penelitian paling mendukung tentang pengaruh pola hidup terhadap kadar kolesterol HDL didapati pada penelitian yang dilakukan oleh Roya et al pada remaja dengan berat badan lebih dan obesitas. Setelah 4 bulan pola hidup para responden dirubah, seperti mengurangi makanmakanan fast food, sarapan teratur, dan meningkatkan aktivitas fisik di rumah dan sekolah, ternyata terjadi peningkatan kadar kolesterol HDL, bahkan pada beberapa sampel tanpa terjadi perubahan antropometri (19).

Penelitian yang dilakukan oleh Tisha et al didapati bahwa obesitas sangat berpengaruh terhadap kelainan pada pembuluh darah, seperti terbentuknya aterosklerosis dan kekakuan dinding pembuluh darah. Hal tersebut ditandai dengan peningkatan kadar hs-CRP pada darah (20). Tam et al menyatakan bahwa sudah didapati tanda-tanda peradangan pembuluh darah pada anak-anak dan remaja dengan obesitas (21). Hal yang sama juga ditemukan pada penelitian yang dilakukan oleh Konstantinos et al pada 54 anak-anak dan remaja dengan persentil $\geq 95$ dan 50 anak-anak dan remaja dengan persentil 85-95, ternyata sudah ditemukan tanda-tanda peradangan pembuluh darah dini (22). Penilitian-penelitian di atas mendukung hasil yang didapat oleh penulis, dalam penelitian yang dilakukan didapati lebih dari setengah remaja obes $(52,9 \%)$ memiliki kadar hs-CRP dengan risiko menengah dan dua sampel (11,8\%) dengan risiko tinggi.

Pada penelitian ini, penulis mendapatkan hasil bahwa kadar kolesterol HDL darah dengan kadar hs-CRP hanya memiliki hubungan yang tidak signifikan (ke arah negatif, lemah). Hasil yang didapat berbeda dengan teori yang ada maupun penelitian-penelitian sebelumnya. Kolesterol HDL meningkatkan ekspresi dari pentraxin 3 (PTX3), yang mana sangat berperan dalam mengatur migrasi dari monosit (23). Migrasi monosit memegang peranan yang sangat penting dalam proses aterosklerosis. Pada tikus yang diinduksi dengan kolesterol HDL, ternyata terjadi peningkatan ekspresi PTX3 pada aorta tikus. Hal yang sama juga dibuktikan dalam penelitian yang pada tikus dengan defisiensi PTX3, ternyata terjadi peningkatan proses inflamasi $(24,25)$. Hal diatas juga didukung oleh jurnal yang ditulis oleh Federica et al yang menyatakan bahwa kolesterol HDL berperan dalam mencegah peradangan pada tubuh terutama pada pembuluh darah (26).

Hubungan antara kadar kolesterol HDL dan kadar hs-CRP juga dapat dijelaskan dengan fakta bahwa respon fase akut pada proses infeksi dan inflamasi menurunkan kadar kolesterol HDL secara bermakna (27). Banyak penelitian juga yang membuktikan bahwa adanya hubungan antara kadar kolesterol HDL dan kadar hs-CRP. Penelitian yang dilakukan Marieeve at al tentang perubahan gaya hidup dalam sebuah populasi didapati peningkatan kadar hsCRP yang diikuti dengan menurunnya kadar kolesterol HDL (28). Pasien dengan dislipidemia yang diterapi dengan memperbaiki profil lipidnya, mengalami penurunan kadar hs-CRP yang 
signifikan seiring dengan peningkatan kadar kolesterol HDL dalam darah $(29,30)$. Teori-teori dan penelitian di atas membuktikan bahwa kadar kolesterol HDL dan kadar hs-CRP memiliki hubungan yang bermakna, tetapi ada banyak faktor yang bisa mempengaruhi hasil yang didapat penulis. Selain faktor genetik dan pola hidup yang membuat kadar kolesterol HDL dan kadar hs-CRP tiap orang berbeda, keterbatasan penulis dalam jumlah sampel juga menjadi faktor yang perlu dipertimbangkan.

\section{SIMPULAN}

Berdasarkan hasil penelitian dan pembahasan dapat disimpulkan bahwa tidak terdapat hubungan antara kadar kolesterol HDL darah dengan kadar hs-CRP pada remaja obes.

\section{UCAPAN TERIMA KASIH}

Ucapan terima kasih disampaikan kepada dr. Murniati Tiho, MKes, AIFO, dr. Yanti M. Mewo, MPdKed, Dr. dr. Nelly Mayulu, MSi, dr. Stefana H. M. Kaligis, MSc, dr. Diana S. Purwanto, MLabMed, dan semua pihak yang baik secara langsung maupun tidak langsung telah menumbuhkan ide atau gagasan dalam pemikiran penulis sehingga dapat menyelesaikan artikel ini.

\section{DAFTAR PUSTAKA}

1. Gee S, Chin D, Ackerson L, Woo D, Howell A. Prevalence of childhood and adolescent overweight and obesity from 2010 to 2013 in an integrated health care delivery system. J Obes. 2013;2013:417907.

2. Finkelstein EA, Trogdon JG, Cohen JW, Dietz W. Annual medical spending attributable to obesity: payer-and service-specific estimates. Health Affairs. 2009;28:822-31.

3. Ministry of Health Republic of Indonesia. Indonesia health profile 2010. Jakarta: Publishing Ministry of Health RI; 2011. p. 227.

4. Adam JMF. Dislipidemia. In: Sudoyo AW, Setiyohadi B, Alwi I, Simadibrata M, Setiati S, editors. Buku ajar ilmu penyakit dalam jilid III. $5^{\text {th }}$ ed. Jakarta: Internal Publishing; 2009. p. 1986-7.

5. McPherson RA. Specific Proteins. In: McPherson RA, Pincus, editors. Henry's clinical diagnosis and management by laboratory methods. $22^{\text {nd }}$ ed. Amsterdam: Elsevier; 2011. p. 260.

6. Seo SM, Baek SH, Jeon HK, Kang SM, Kim DS, Kim WS, et al. Correlations between the level of high-sensitivity C-reactive protein and cardiovasculer risk factors in korean adults with cardiovasculer disease or diabetes mellitus: The CALLISTO study. J Atheroscler Thromb. 2013;20(7):616-22.

7. Yang SP, Gong CX, Cao BY, Yan C. Relationship between serum high-sensitivity C-reactive protein and obesity and impaired glycose metabolism in children and adolescents. Zhonghua Er Ke Za Zhi. 2006;44(12):933-6.

8. Whitney LB, Craig AJ, Kelly S, Katie CC, Tiffany RD, Jennette PM, et al. Obese Mexican American children have elevated MCP-1, TNF- $\alpha$, monocyte concentration, and dyslipidemia. Pediatrics. 2012;129:5.

9. Sabine M, Carry MR, Judith EB, Olga HB, Jacob CD. Cardiometabolic risk factors and quality of life in severly obese children and adolescents in the Netherlands. BMC Pediatric. 2013;13:62.

10. Sargowo D, Wijayanto E, Diana L, Andriani S, Handaya AY Fatmawati H, et al. Pengaruh komposisi asupan makanan terhadap komponen sindroma metabolik pada remaja di Kota Malang. Hibah Pasca. 2009;7:22-3.

11. Ebe D, Veronika N, Ram W, Nicola S, Bridget P, Mary S, et al. Etnic differences in lipoprotein subclasses in obese adolescent: importance of liver and intraabdominal fat accretion. Am J Clin Nutr. 2010;92:500-8. 
12. Aprami TM. Risiko terjadinya dislipidemia pada remaja 12-14 tahun dengan berat badan lahir rendah. J Univ Indon. 2010;24:15-9.

13. Feng Q, Vickers KC, Anderson MP, Levin MG, Chen W, Harrison DG, et al. A common functional promoter variant links CNR1 gene expression to HDL cholesterol level. Nat Commun. 2013;4:1-18.

14. Zhang B, Kawachi E, Miura S, Uehara Y, Matsunaga A, Kuroki M. Therapeutic approaches to the regulation of metabolism of high-density lipoprotein. J Circ. 2013;12:2652-63.

15. Kodama S, Tanaka S, Saito K, Shu M, Sone Y, Onitake F, et al. Effect of aerobic exercise training on serum level of high-density lipoprotein cholesterol:meta-analysis. Arch Intern Med. 2007;167:999-1008.

16. Di Renzo L, Rizzo M, Sarlo F, Colica C, Iacopino L, Domino E, et al. Effects of dark chocolate in a population of normal weight obese woman: a pilot study. Eur Rev Med Pharmacol Sci. 2013;17:2257-66.

17. Daniel CR, Paloma AV, Emma CM, Clara EM, Griselda BC, Roopa M. Effect of tomato consumption on high-density lipoprotein cholesterol level: a randomized, single-blinded, controlled clinical trial. Dov. 2013;6:263-73.

18. Irish E, Raika R, Georg A, Jukka M, Pauli P, Pirjo M, et al. Favorable effects of berry consumption on platelet function, blood pressure, and HDL cholesterol. Am J Clin Nutr. 2008;87:323-31.

19. Roya K, Mahin H, Ahmad SH, Shohreh GS. Changes in serum lipid profile of obese children and adolescents following a lifestyle modification course. ARYA Atheroscler J. 2012;8(3):1438.

20. Tisha MB, Kodlipet D, Jingly W, Rong Y, Allison B, Couillard, et al. Moderate obesity and endothelial dysfunction in humans: influence of gender and systemic inflammation. Physiol Rep. 2013;1(3):1-10.

21. Tam CS, Clement K, Baur LA, Tirdjiman J. Obesity and low-grade inflammation: a pediatric perspective. Obes Rev, 2010;11:118-26.

22. Konstantinos K, Maria P, Konstantina K, Nikalaos K, Maria P, Kiriaki T. High-sensitivity C-reactive protein levels and metabolic disorder in obese and overweight children and adolescents. J Clin Res Pediatr Endocrinol. 2013;5(1):44-9.

23. Norata GD, Marchesi P, Pirillo A, Uboldi P, Chiesa G, Maina V, et al. Long pentraxin 3, a key component of innate immunity, is modulated by high-density lipoprotein in endothelial cells. Aterioscler Thromb Vasc Biol. 2008;28:925-31.

24. Norata GD, Garlanda C, Catapano AL. The long pentraxin PTX 3: a modulator of the immunoinflammatory response in atherosclerosis and cardiovasculer disease. Trends Cardiovasc Med. 2010;20:35-40.

25. Norata GD, Marchesi P, Pulakazhi VK, Pasqualini F, Anselmo A, Moalli F. Deficiency of the long pentraxin PTX 3 promotes vascular inflammation and atherosclerosis. Circulation. 2009;120:699-708.

26. Federica S, Alberico LC, Giuseppe DN. High density lipoprotein and atherosclerotic: emerging aspects. J Geriatr Cardiol. 2012;9:401-7.

27. Khovidhunkit W, Kim MS, Memon RA, Shigenaga JK, Moser AH, Feingold KR, et al. Effects of infection and inflammation on lipid and lipoprotein metabolism: mecanisms and consequences to the host. J Lipid Res. 2004;45:1169-96.

28. Marie-Eve L, Eric D, Marie-Ladivine CD, Patrick C, Benoit L. Population-based study of high plasma C-reactive protein concentrations among the Inuit of Nunavik. Int J Circumpolar Health. 2012;71:1-9.

29. Robert HK, Barbara MR, Brian F, Alice D, Barbara T, Thuy N. et al. The SLIM study: sloniacin and atorvastatin treatment of lipoproteins and inflammatory markers in combined hiperlipidemia. J Clin Lipidol. 2009;3(3):167-78.

30. Robert JG, Jean GM, Paul MR. Tracking of high-sensitivity C-reactive protein after an initially elevated concentration: The JUPITER study. Clin Chem. 2009;55(2):305-12. 